\title{
Rosiglitazone inhibits metastasis development of a murine mammary tumor cell line LMM3
}

\author{
Gabriela Magenta, Ximena Borenstein, Romina Rolando and \\ María Adela Jasnis*
}

Address: Research Area, Institute of Oncology AH Roffo. Av. San Martín 5481 (CP 1417). Buenos Aires, Argentina

Email: Gabriela Magenta - gaby.magenta@gmail.com; Ximena Borenstein - ximena_bores@hotmail.com; Romina Rolando - rominanoelia@speedy.com.ar; María Adela Jasnis* - majasnis@fibertel.com.ar

* Corresponding author

Published: 8 February 2008

BMC Cancer 2008, 8:47 doi:10.1186/147I-2407-8-47
Received: 30 March 2007

Accepted: 8 February 2008

This article is available from: http://www.biomedcentral.com//47/-2407/8/47

(c) 2008 Magenta et al; licensee BioMed Central Ltd.

This is an Open Access article distributed under the terms of the Creative Commons Attribution License (http://creativecommons.org/licenses/by/2.0), which permits unrestricted use, distribution, and reproduction in any medium, provided the original work is properly cited.

\begin{abstract}
Background: Activation of peroxisome proliferator-activated receptors $\gamma$ (PPAR $\gamma$ ) induces diverse effects on cancer cells. The thiazolidinediones (TZDs), such as troglitazone and ciglitazone, are PPAR $\gamma$ agonists exhibiting antitumor activities; however, the underlying mechanism remains inconclusive. Rosiglitazone (RGZ), a synthetic ligand of PPAR $\gamma$ used in the treatment of Type 2 diabetes, inhibits growth of some tumor cells and is involved in other processes related to cancer progression. Opposing results have also been reported with different ligands on tumor cells. The purpose of this study was to determine if RGZ and $15 \mathrm{~d}-\mathrm{PG} \mathrm{J}_{2}$ induce antitumor effects in vivo and in vitro on the murine mammary tumor cell line LMM3.
\end{abstract}

Methods: The effect on LMM3 cell viability and nitric oxide (NO) production of different doses of RGZ, I5-dPG $]_{2}$, BADGE and GW9662 were determined using the MTS colorimetric assay and the Griess reaction respectively. In vivo effect of orally administration of RGZ on tumor progression was evaluated either on s.c. primary tumors as well as on experimental metastasis. Cell adhesion, migration (wound assay) and invasion in Transwells were performed. Metalloproteinase activity (MMP) was determined by zymography in conditioned media from RGZ treated tumor cells. PPAR $\gamma$ expression was detected by inmunohistochemistry in formalin fixed tumors and by western blot in tumor cell lysates.

Results: RGZ orally administered to tumor-bearing mice decreased the number of experimental lung metastases without affecting primary s.c. tumor growth. Tumor cell adhesion and migration, as well as metalloproteinase MMP-9 activity, decreased in the presence of I $\mu M$ RGZ (noncytotoxic dose). RGZ induced PPAR $\gamma$ protein expression in LMM3 tumors. Although metabolic activity -measured by MTS assay- diminished with I-100 $\mu$ M RGZ, I $\mu$ M-treated cells recovered their proliferating capacity while $100 \mu \mathrm{M}$ treated cells died. The PPAR $\gamma$ antagonist Biphenol A diglicydyl ether (BADGE) did not affect RGZ activity. On the contrary, the specific antagonist GW9662 completely abrogated RGZ-induced decrease in cell viability. A decrease in NO levels was detected in the presence of either I or $100 \mu M$ RGZ. The natural ligand $I 5 \mathrm{~d}-\mathrm{PG} \mathrm{J}_{2}$ did not affect metabolic activity although it induced a significant decrease in NO production.

Conclusion: A significant decrease in the number of experimental LMM3 lung metastasis, but not on primary tumor growth, after oral RGZ administration was observed. In vitro, $100 \mu \mathrm{MRGZ}$ also 
reduced cell viability and NO production, while no changes were observed in the presence of I5d$P G J_{2}$. BADGE did not reverse RGZ effect while the antagonist GW9662 completely abrogated it, suggesting a PPAR $\gamma$ - dependent mechanism. Inhibition of lung metastatic nodules by RGZ administered in vivo, might be associated with the observed decrease in MMP-9 expression, in cell adhesion, migration and invasion. RGZ augmented its expression. PPAR $\gamma$ was detected in cell lysates by western blot and by immunohistochemistry in tumors from RGZ-treated mice. In summary we can suggest that RGZ or any other TZDs might be possible future approaches in the treatment of metastasis of PPAR $\gamma$-expressing cells.

\section{Background}

Peroxisome proliferator activated receptors (PPARs) belong to a ligand-dependent nuclear receptor family that regulates multiple metabolic processes associated with $\beta$ oxidation, glucose utilization and cholesterol transport. Three subtypes of PPARs $(\alpha, \beta / \delta$ and $\gamma$ ) have been identified exhibiting distinct tissue distribution and associated with selective ligands [1]. PPAR $\gamma$ is broadly characterized and it is highly expressed in adipose and adrenal tissues, colon epithelia, T and B lymphocytes and macrophages.

The heterodimer PPAR $\gamma$-RXR (retinoic acid receptor) binds specifically to response elements and works as a transcription factor [2]. Because of the recruitment of different coactivators PPAR $\gamma$ shows distinctive biological activities [3]. As seen in monocytes and macrophages, ligands can repress the transcription of proinflammatory products such as TNF, IL-1 and iNOS (inducible nitric oxide synthase) $[4,5]$.

The role of PPARs is controversial in tumor biology. PPAR $\gamma$ ligands have anticancer effects against a wide variety of neoplastic cells in vitro and in vivo but target genes involved in this activity remain unclear [6]. Many authors have documented induction of differentiation and apoptosis by ligands of PPAR $\gamma$, particularly in non-small cell lung cancer, glioblastoma, prostate, colon, pituitary and liver cancer cells [6-8]. Invasion of breast cancer cells, that often express prominent levels of PPAR $\gamma$, is inhibited by rosiglitazone (RGZ) in a PPAR $\gamma$-independent manner [9].

Since we first found that murine mammary LMM3 tumor cells expressed PPAR $\gamma$ protein, we performed in vivo experiments to analyze the effect of RGZ, the synthetic compound with high affinity for PPAR $\gamma$, on primary tumor and lung metastasis development. Furthermore, we studied the effects of RGZ on tumor cell viability, adhesion, migration and levels of MMP-9 and NO production. Activity of the natural ligand 15 -deoxy- $\Delta^{12,14}-\mathrm{PGJ}_{2}(15 \mathrm{~d}-$ $\mathrm{PGJ}_{2}$ ) was studied. Experiments with the PPAR $\gamma$ antagonist bisphenol A diglycidyl ether (BADGE) [10] and GW 9662 [11] were included to evaluate the roles of PPAR $\gamma$ dependent and independent signaling pathways in several responses. According to our results, RGZ might be consid- ered as a possible therapeutic, able to inhibit tumor cell growth in secondary tissues affecting different steps of the metastatic cascade. The involvement of the inflammatory milieu associated with tumor development must be also considered.

\section{Methods \\ Reagents}

15-deoxy-delta ${ }^{12,14}$-prostaglandin $\mathrm{J}_{2}$ (15d-PGJ ${ }_{2}$, Cayman Chemical Company, Ann Arbor, MI, USA) and Rosiglitazone -RGZ- (ELEA Lab, Argentina) were dissolved in $100 \%$ and $70 \%$ ethanol respectively. Bisphenol A diglycidyl ether (BADGE, FLUKA, Chemical GmbH Buchs, Switzerland), was dissolved in 70\% ethanol and GW9662 (Sigma-Aldrich, USA) in DMSO. Each of the solvents was used as a control without significant effect. LPS (SigmaAldrich, Missouri, USA.) was used at $500 \mu \mathrm{g} / \mathrm{ml}$.

\section{Tumor cell culture}

The tumor cell line LMM3, syngeneic to BALB/C, derived from spontaneous lung metastasis from the primary MM3 mammary tumor, was obtained and established in our Research Area [12]. LMM3 cells were maintained in MEM medium (Gibco, BRL) with $3 \mathrm{mM} \mathrm{L}$-glutamine, $80 \mu \mathrm{M} / \mathrm{ml}$ gentamycin, supplemented with $5 \%$ fetal calf serum (FCS) (Bioser, Argentina) and cultured in a humidified $5 \% \mathrm{CO}_{2}$ air atmosphere at $37^{\circ} \mathrm{C}$. Serial passages of confluent monolayers were performed by detaching cells with trypsin (0.25\% trypsin and $0.075 \%$ EDTA in $\mathrm{CA}^{++}$and $\mathrm{Mg}^{++}$free PBS). Medium was replaced every two days. LMM3 cells were used for in vitro and in vivo studies.

\section{Cell viability}

$1 \times 10^{4}$ cells $/ 200 \mu \mathrm{L} \mathrm{MEM}+10 \%$ FCS were seeded in 96well plates (CELLSTAR, Greiner Bio-One, USA). After $2 \mathrm{~h}$ adhesion, cells were washed and fresh medium with RGZ or 15d-PGJ2 (0.01-100 uM) without FCS was added. When used, BADGE $(10 \mu \mathrm{M})$ was added $15 \mathrm{~min}$ and GW$9662(1,10,20 \mu \mathrm{M}) 1 \mathrm{~h}$ before RGZ. After $24 \mathrm{~h}$ incubation, metabolic activity was measured using the MTS assay (CellTiter96 AQueous Non-radioactive Cell Proliferation Assay, Promega, USA) an ELISA plate reader (Bio Rad) at $492 \mathrm{~nm}$ wavelength. In addition, cells were cultured for 24-48 h with 1-100 uM RGZ and then placed back in 
fresh medium for additional $48 \mathrm{~h}$. Number of viable cells was quantified by Trypan blue exclusion test every $24 \mathrm{~h}$ up to $96 \mathrm{~h}$.

\section{NO production}

The level of NO was estimated by measuring nitrite levels with Griess reagent in extracellular medium from cells incubated overnight with RGZ and 15d-PGJ ${ }_{2}$. Briefly, 100 $\mu \mathrm{l}$ cell-free supernatants were added to equal volume of Griess reagent [13] (1\% sulphanyl amine in 30\% acetic acid with $0.1 \% \mathrm{~N}$-1-naphtyl ethylendiamine dihydrochloride in $60 \%$ acetic acid). Absorbance was measured at $540 \mathrm{~nm}$ with an ELISA reader. Different concentrations of sodium nitrite were used to construct a standard curve.

\section{In vivo tumor growth}

At day 0, female inbred BALB/c mice (aged 6-8 weeks) were s.c. inoculated into the flank with LMM3 cells $(3 \times$ $10^{5} / 0.1 \mathrm{ml}$ ). After inoculation, mice were randomized into 2 groups (each with $\mathrm{n}=10$ ). One group was administered a concentration of $100 \mu \mathrm{M}$ RGZ in the drinking water while control group was administered with ethanol $0.01 \% \mathrm{v} / \mathrm{v}$. Treatment continued for 30 days (total duration of the experiment). Animals were scored for tumor growth three times/week by measuring the smallest and largest diameters of the s.c. tumors with a Vernier caliper. At the end of the experiment, some tumors were excised to determine PPAR $\gamma$ expression. Mice were maintained under guidelines established in the guide for Care and Use of Laboratory Animals (NIH publications, 1986).

\section{Experimental metastasis in vivo}

$2 \times 10^{5}$ LMM3 cells were i.v. injected into the tail vein. RGZ (100 uM) was administered in the drinking water. Ethanol was administered to control mice. At day 30 mice were sacrificed and lungs were examined for metastatic lesions (number and size) under stereoscopic microscope (Bausch \& Lomb).

\section{Adhesion assay}

RGZ $(1 \mu \mathrm{M})$ was added to LMM3 cells during the process of adhesion to 6-well plates in the absence of FCS. After 2 $\mathrm{h}$, the number of non-adherent cells was determined by counting cells in the supernatants ("process of adhesion assay"). In another set of experiments, RGZ was added for $6 \mathrm{~h}$ to already attached cells and the number of cells that could be obtained by aspiration was determined. ("resistance to aspiration assay"). When used, $10 \mu \mathrm{M}$ BADGE was added 15 min before RGZ.

\section{Migration Assay}

A wound of $400 \mu \mathrm{m}$ was made on confluent cell monolayers in 6-well plates and $10 \mu \mathrm{M}$ RGZ with or without BADGE was added ("wound assay"). Microphotographs taken immediately after performing the wound (T0) and 24h later (T1) were analyzed using the Image-ProPlus 4.5 software program. Difference between cell-free area at T0 and $\mathrm{T} 1$ was quantified.

\section{Invasion assay}

$50 \mu \mathrm{l} 0.1 \%$ gelatine and $100 \mu \mathrm{l}$ matrigel were loaded in the lower and upper part respectively of Transwell chambers. Using fibronectin $(4 \mu \mathrm{g} / \mathrm{ml})$ as chemoattractant $2 \times$ $10^{5} \mathrm{LMM} 3$ were seeded and treated with $1 \mu \mathrm{M}$ RGZ, $10 \mu \mathrm{M}$ BADGE or the combination of both. After $20 \mathrm{~h}$ culture at $37^{\circ} \mathrm{C}$, membranes were fixed and stained with DAPI. Cell invasion was determined counting the number of cells adhered to the membranes using a fluorescence microscope (400× magnification). 10 fields were counted per group.

\section{Gelatin zymography}

Gelatinolytic MMP activity was determined on substrateimpregnated gels. Briefly, samples were separated on SDS$9 \%$ polyacrylamide gels containing $1 \mathrm{mg} / \mathrm{ml}$ copolymerized gelatin (Difco, Detroit, MI) under non-reducing conditions. These gels were washed twice with $2.5 \%$ Triton X100 , incubated for 24 hours at $37^{\circ} \mathrm{C}$ in $0.25 \mathrm{M}$ Tris- $\mathrm{HCl}$, $1 \mathrm{M} \mathrm{NaCl}, 25 \mathrm{mM} \mathrm{CaCl}_{2}$ at $\mathrm{pH} 7.4$, and stained with $0.5 \%$ Coomassie G 250 (Bio-Rad, Richmond, CA) in methanol/ acetic acid/water (30:10:60). The clear lysed areas (white bands) on the stained gels were measured with a GS-700 densitometer (Bio-Rad, Hercules, CA, USA).

\section{Immunohistochemistry}

$\operatorname{PPAR} \gamma$ expression was analyzed in formalin-fixed, paraffin-embedded sections of LMM3 tumors. Briefly, endogenous peroxidase activity was blocked with $0.6 \%$ hydrogen peroxide. Antigen retrieval was performed using microwave oven irradiation in citrate buffer $(\mathrm{pH}: 6)$. Slides were incubated for $1 \mathrm{~h}$ with normal goat serum (1:10) (Vector Labs, Burlingame, CA) and overnight with rabbit specific monoclonal antibody anti-PPAR $\gamma(\mathrm{H}-100$, Santa Cruz Biotechnology, USA) diluted 1:20. Sections were incubated with biotinylated goat anti-rabbit IgG (Sigma-Aldrich) diluted 1:500 for $60 \mathrm{~min}$, followed by incubation with peroxidase-conjugated streptavidin diluted 1:3000 in phosphate-buffered saline for $45 \mathrm{~min}$. Peroxidase reaction was performed using $0.02 \% 3$, 3'diaminobenzidine tetrahydrochloride and $0.01 \%$ hydrogen peroxide and co-staining with hematoxylin (1 min). As negative control, the primary antibody was omitted.

\section{Detection of PPAR $\gamma$ by western blot}

LMM3 cell monolayers were rinsed twice with ice-cold PBS and scraped into $100 \mathrm{ul}$ RIPA lysis buffer: $(50 \mathrm{mM}$ Tris-HCl, pH 7.5; $150 \mathrm{mM} \mathrm{NaCl}, 10 \mathrm{mM}$ EDTA, $1 \%$ NP40). Lysis was completed by sonication and centrifugation. Protein content was determined with Bradford reagent, using bovine serum albumin as standard. Sample 
electrophoresis (100 $\mu \mathrm{g}$ protein/25 $\mu \mathrm{l} /$ lane) was performed on $10 \%$ sodium dodecyl sulfate polyacrylamide gels (SDS-PAGE). Proteins were transferred to nitrocellulose membranes and incubated overnight with mouse monoclonal antibody anti-PPAR $\gamma$, diluted 1:100. The secondary antibody, conjugated with alkaline phosphatase anti-rabbit IgG (Sigma-Aldrich), was added for $1 \mathrm{~h}$ at $37^{\circ} \mathrm{C}$. Proteins were visualized using a mixture of NBT/ BCPI (Sigma-Aldrich) and scanned with a computerized densitometer (GS-700Calibrated Densitometer Bio-Rad Laboratories, Richmond, CA).

\section{Statistical analysis}

Results are expressed as mean \pm standard deviation. Significance of differences was calculated by Student's t test or Mann Whitney. All experiments were performed by triplicate and repeated at least three times, with comparable results.

\section{Results}

RGZ and I5d-PGJ2 differentially affect $L M M 3$ cell viability and NO production

1 and $100 \mu \mathrm{M}$ RGZ reduced metabolic activity in 50\%, measured with MTS assay (Fig 1A). To determine if this inhibition was associated with a decrease in cell viability, the number of viable cells was quantified every $24 \mathrm{~h}$ up to $96 \mathrm{~h}$ (Trypan blue exclusion test). After $72 \mathrm{~h}$, control cells reached a plateau and the number of viable cells quadrupled the number of seeded cells. In cells cultured with 1 $\mu \mathrm{M}$ RGZ, no significant increase in cell number was observed during the first $48 \mathrm{~h}$. At this point cells began to recover their proliferating capacity, and reached control numbers at $96 \mathrm{~h}$. On the contrary, cells treated with 100 uM RGZ almost died after $72 \mathrm{~h}$ (Fig 1B). 15d-PG) ${ }_{2}$ did not affect metabolic activity.

Since inflammation is an important component of tumor microenvironment, we examined the effect RGZ in cell cultures with LPS. Addition of LPS completely abrogated the inhibitory effect of 1-100 $\mu \mathrm{M}$ RGZ (Fig 1A). Previous results have shown that NO seems to be a protective/survival factor for LMM3 cells, since increased cell death was detected in the presence of NOS inhibitors such as LNAME ( $\mathrm{N}^{\mathrm{G}}$-nitro-L-arginine methyl esther) and AG (aminoguanidine) (Jasnis MA et al, unpublished results). NO production decreased $40 \%$ in cultures with 10 $\mu \mathrm{M} 15 \mathrm{~d}-\mathrm{PGJ}_{2}$ and $1-100 \mu \mathrm{M} \mathrm{RGZ}$; the presence of LPS reversed this effect and induced a significant increase in NO levels (Fig 1C).

\section{Effect of BADGE and GW9662 on cell viability}

Since BADGE and GW9662 are PPAR $\gamma$ antagonists, we studied their effects to assess the relative roles for PPAR $\gamma$ dependent and independent biological responses. $10 \mu \mathrm{M}$ BADGE and GW9662 (1, 10 and $20 \mu \mathrm{M})$ per ser did not
A.
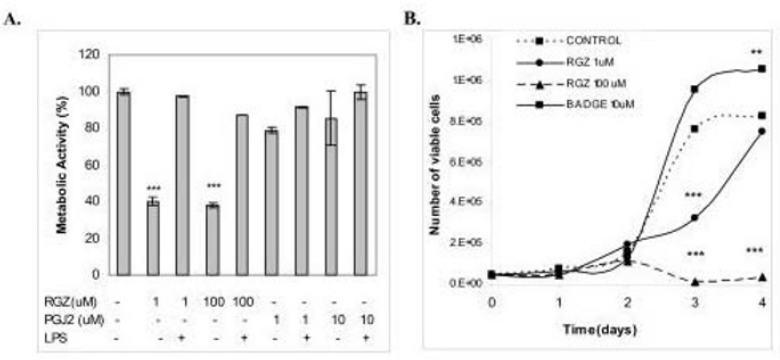

c.

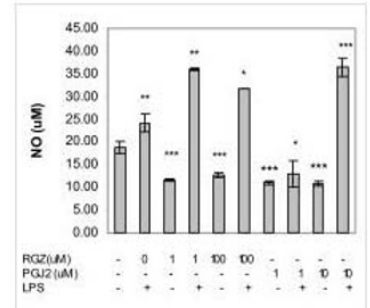

Figure I

Effect of RGZ and I5d-PGJ ${ }_{2}$ on LMM3 cell viability. A. MTS assay was used to determine cell metabolic activity after $24 \mathrm{~h}$-culture in the presence of RGZ (I and $100 \mu \mathrm{M})$ and $15 \mathrm{~d}-\mathrm{PG} \mathrm{J}_{2}$ (I and $\left.10 \mathrm{uM}\right)$ with or without LPS $(500 \mu \mathrm{g} / \mathrm{mL})$. Results are expressed as absorbance (\% of control considered $100 \%$ ) $* * *$ p $<0.00$ I vs. control. B. The growth-kinetics of LMM3 cells in the presence of I0 $\mu$ M BADGE, I and 100 $\mu M R G Z$ is shown (**p $<0.01,{ }^{* * *} p<0.001$ vs. control). C. NO production by LMM3 tumor cells cultured during $24 \mathrm{~h}$ with RGZ (I and I00 $\mu \mathrm{M})$ or $\mid 5 \mathrm{~d}-\mathrm{PG}]_{2}(\mathrm{I}$ and $10 \mu \mathrm{M}$ ) was measured in the supernatants using Griess reagent. Experiments were performed with and without LPS. Results are expressed as $\mu \mathrm{MNO}_{2}$ respect to a control curve of nitrite. A and $B$ show the results of one representative experiment of three independent assays performed by triplicate with similar results. ${ }^{* *} p<0.01 ; * * *_{p}<0.001$ vs control.

affect cell metabolic activity while higher concentrations of BADGE were cytotoxic (data not shown). As shown in Fig 2a, BADGE did not behave as an antagonist. Moreover, a more significant decrease in metabolic activity with BADGE + RGZ was detected compared to RGZ alone. The same effects were observed on NO production (Fig 2a, numbers between parentheses). On the other hand, GW9662, an irreversible PPAR $\gamma$ antagonist, completely reversed the inhibition of cell metabolic activity induced by RGZ 1 and $100 \mu \mathrm{M}$. (Fig 2b)

\section{Tumor and metastasis growth}

Tumor cells were directly inoculated into the tail vein and differences in lung metastasis were detected between untreated and RGZ-treated mice: median (range): 21 (5- 
A.

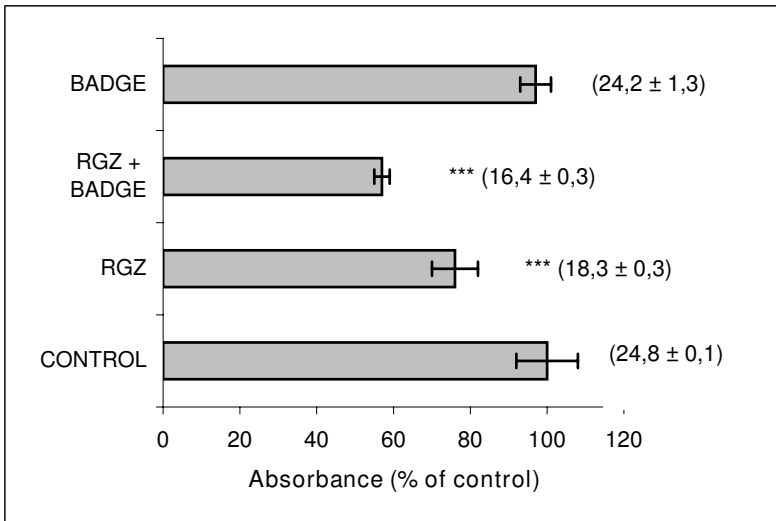

B.

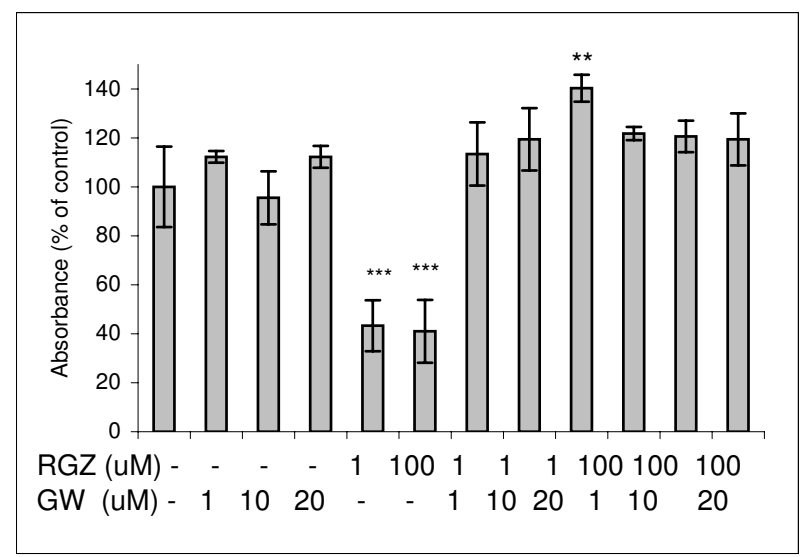

Figure 2

A. Effect of BADGE on cell metabolic activity. BADGE $(10 \mu \mathrm{M})$ was added to cell cultures alone or 15 minutes before $100 \mu \mathrm{M}$ RGZ. After $24 \mathrm{~h}$, metabolic activity was determined by MTS assay. BADGE per se had no effect. BADGE + RGZ diminished metabolic activity compared to RGZ alone ( $* * * p<0.001)$. NO levels are shown between parentheses $(\mu M)$. B. Effect of GW-9662 on LMM3 cells. GW-9662 (I, I0, and $20 \mu \mathrm{M})$ was added to cell cultures I h before $100 \mu \mathrm{M}$ RGZ. After $24 \mathrm{~h}$, metabolic activity was determined by MTS assay. (*** $p<0.001$ vs. control untreated cultures).

$36)$ and 7 (0-17) respectively, $\mathrm{p}<0.0001$ (Fig 3A). These differences were observed in metastasis with diameters up to $2 \mathrm{~mm}$. However, oral administration of RGZ did not affect primary s.c. tumor growth (Fig 3B).

Effect of RGZ on cell adhesion and migration

During early cell attachment ( $2 \mathrm{~h}), 1 \mu \mathrm{M}$ RGZ significantly inhibited tumor adhesion. The addition of BADGE did not reverse this effect, and BADGE per se diminished cell
A.

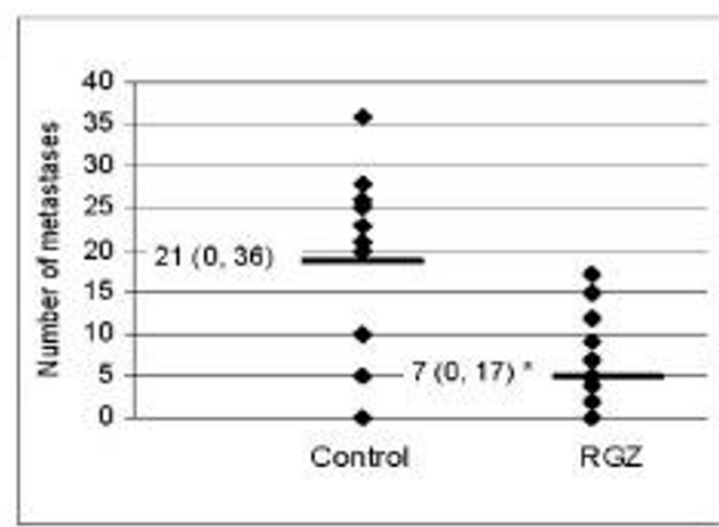

B.

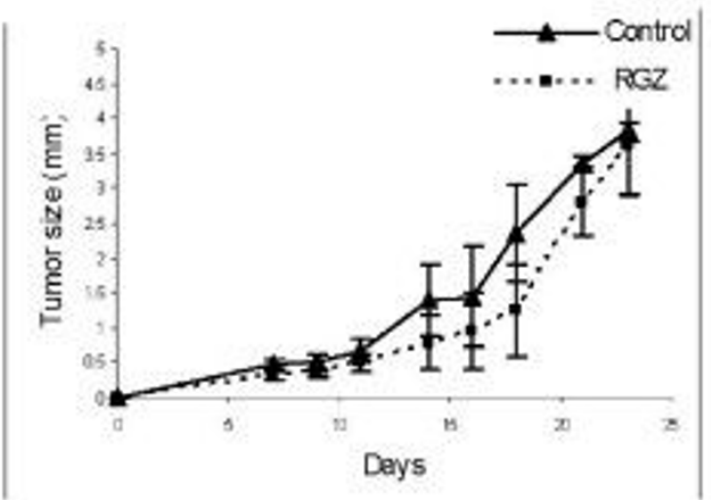

Figure 3

Effect of RGZ on experimental lung metastases and primary tumor growth. A. Lung metastasis. On day 0 , mice ( $n=10 /$ group) were i.v. inoculated with LMM3 cells into the tail vein. Experimental group was orally treated with $100 \mu$ MRGZ while control group only with ethanol in drinking water. On day 30 , mice were sacrificed and number and size of lung metastatic nodules were recorded under microscope. Each point in the figure represents total number of metastases/lung/mice. All nodules were $\leq 2 \mathrm{~mm}$ in diameter. Median (range) is shown on the horizontal line $(p<0.007)$. One experiment of three with similar results is shown. B. Primary tumor. Perpendicular diameters of s.c. growing tumors were measured three times/week since day 7 (latency) up to day 25. Average of tumor size at each point was calculated as follows: $\sqrt{ }(d x D), d=$ minor diameter, $D=$ major diameter. Error bars represent SD $(n=10)$. No significant difference was observed at any time during tumor progression between groups.

adhesion (Fig 4A). After 8 h adhesion $77 \%$ of control cells were resistant to aspiration. Addition of RGZ diminished by $50 \%$ cell attachment (50\% attached cells) (Fig 4B). It is noteworthy that BADGE could reverse the inhibitory effect completely (Fig 4B). A reduction of 59\% in tumor 


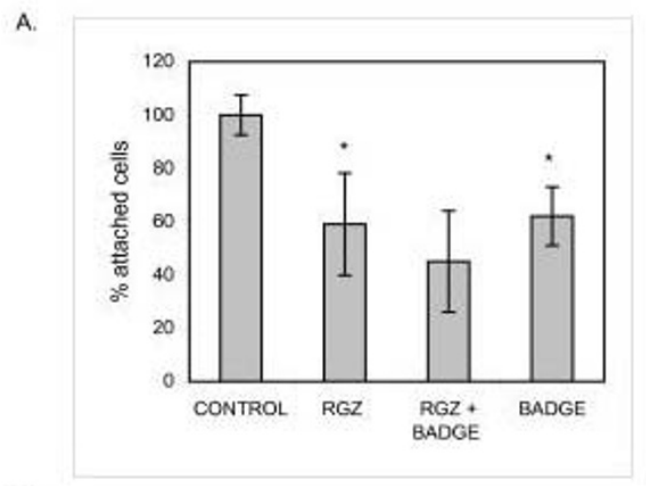

B.

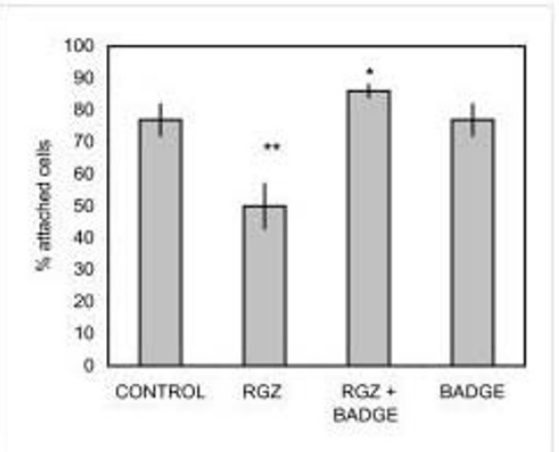

c.

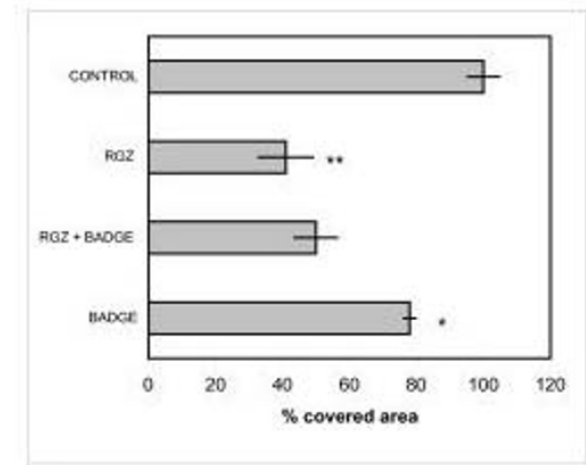

\section{Figure 4}

Effect of RGZ on cell adhesion and migration. A. LMM3 cells were cultured with I $\mu$ MRGZ and $10 \mu M$ BADGE alone or in combination. Non-adherent cells were counted after $2 \mathrm{~h}$ with a haemocytometer. $* \mathrm{p}<0.05 \mathrm{vs}$. control. No differences were observed between RGZ and

RGZ+BADGE. B. Already attached tumor cells were treated with RGZ with or without BADGE. The number of detached cells after $8 \mathrm{~h}$ was considered as a measure of "resistance to aspiration" ** $p<0.0$ I vs. control; * $p<0.05$ vs. RGZ; C. Cell migration in the presence of I $\mu \mathrm{M}$ RGZ, I0 $\mu$ M BADGE or the combination of both was evaluated using the "wound assay". The \% of covered area after $24 \mathrm{~h}$ treatment, compared to control is shown. In all cases representative results of three experiments performed by triplicate are shown.

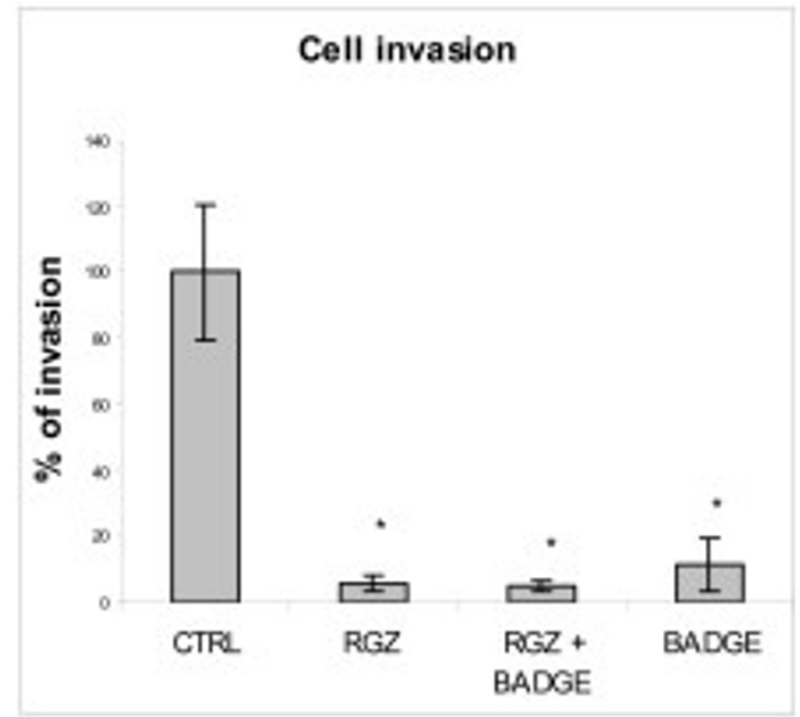

\section{Figure 5}

Effect on Cell Invasion in Matrigel. Inhibition in cell invasion in matrigel was detected in all cultures, with no differences between I $\mu \mathrm{M}$ RGZ and I0 $\mu$ M BADGE alone or in combination $\left(*_{p}<0.05\right)$.

cell migration was observed in the presence of RGZ. This result was not reversed by BADGE -which slightly inhibited cell migration per se. (Fig 4C).

\section{Cell Invasion in Matrigel}

RGZ and BADGE at non-toxic doses, alone or in combination, completely annulled LMM3 cell invasion in Matrigel (Fig 5).

\section{Production of matrix metalloproteases}

MMP activity was analyzed by gelatin and casein zymography in conditioned media of control, $1 \mu \mathrm{M}$ RGZ and 10 $\mu \mathrm{M}$ BADGE treated LMM3 cells. Gelatin zymography revealed bands corresponding to mouse mammary gland latent MMP-9 (LMMP-9). A decrease in the levels of LMMP-9 was detected in conditioned media from RGZ and BADGE treated cells compared to control untreated cells. (Fig. 6)

\section{Effects of RGZ on PPAR $\gamma$ expression}

Perinuclear staining of PPAR $\gamma$ was detected in almost all tumor cells from RGZ-treated mice (Fig 7 right panel), while no expression could be found in tumors from untreated mice (Fig 7 left panel). In treated and untreated tumor bearing mice, adipocytes and endothelium showed intense PPAR $\gamma$ staining. RGZ enhanced the expression of 

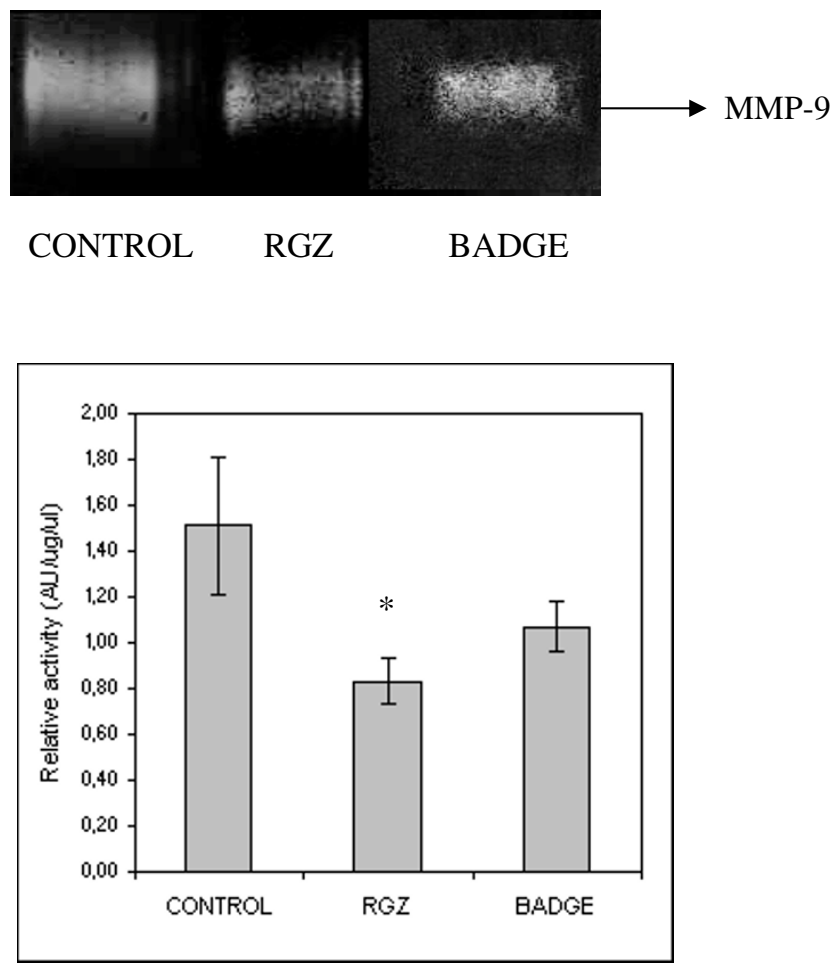

\section{Figure 6}

Effects on MMP activity. MMP activity was determined in conditioned media from control LMM3 tumor cells (left), I uMRGZ-treated (middle) and $10 \mu$ M BADGE-treated cells (right). RGZ induced a decrease on the expression of latent MMP-9 (LMMP-9) compared to control (*p < 0.05).

PPAR $\gamma$ protein in LMM3 cells, compared to control cells (Western blot, Fig. 7B).

\section{Discussion}

The main finding of our experiments is the decrease in the number of experimental LMM3 lung metastasis after oral RGZ administration without any effect on primary tumor growth. Metastasis inhibition could be correlated with in vitro results of metabolic activity and cell viability reduction by $100 \mu \mathrm{MRGZ} .1 \mu \mathrm{M}$ RGZ only induced the decrease in metabolic activity without affecting cell viability, suggesting a possible arrest in cell cycle. It is probable that oral ingestion of a solution $100 \mu \mathrm{M}$ does not reach this same plasmatic concentration, but most likely achievable doses obtained in vivo are closer to $1 \mu \mathrm{M}$., partially explaining the absence of in vivo tumor killing. $10 \mu \mathrm{M}$ BADGE per se significantly enhanced the number of viable cells over control cultures, showing that at non-toxic doses, it was able to stimulate cell proliferation. Moreover, BADGE not only did not reverse the inhibitory effect of RGZ, but instead acted to further decrease cell metabolism (Fig 2A). Our results agree with those of Lea et al [14] who reported that BADGE and diclofenac failed to reverse the inhibitory
A.
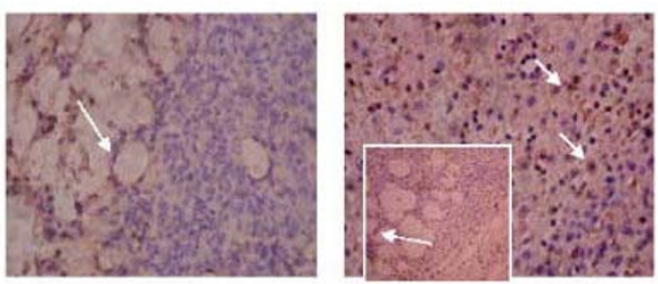

B.

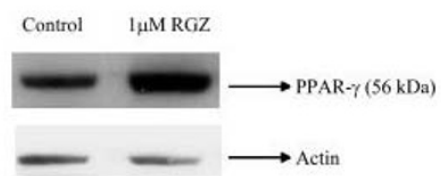

\section{Figure 7}

A. PPAR $\gamma$ expression in LMM3. Representative immunostaining for PPAR $\gamma$ in LMM3 cells from fresh tumor samples obtained from untreated mice (right panel) and from RGZ-orally treated (I00 $\mu \mathrm{M}$ ) (left panel). Almost all tumor cells were positive in tumors from RGZ treated animals while no staining was detected in LMM3 cells from tumors from untreated animals. Adipocytes and endothelial cells were positive in both groups. Photograph magnification, $\times 400$. B. Western blot and immunostaining of PPAR $\gamma$. Cell lysates were prepared from LMM3 tumor cells treated or not with I $\mu$ M RGZ for $24 \mathrm{~h}$. Western blot analysis was performed with specific antibody anti PPAR $\gamma$.

effect of ciglitazone on growth of human breast cancer and mouse eritroleukemia cells. Although it has been widely reported that doses near to $100 \mathrm{uM}$ are needed for BADGE to behave as a PPAR inhibitor, we could not use higher doses than $10 \mathrm{uM}$ because, in our system, they were cytotoxic. BADGE has been shown to serve as a PPAR $\gamma$ agonist in RAW 264.7 cells, human monocytes and in some epithelial cells $[15,16]$ and as an inducer of apoptosis in some tumor cells [17]. The mechanisms responsible for the effects of RGZ on LMM3 viability seem to involve PPAR $\gamma$-dependent signals since we found that changes in cell metabolism induced by RGZ were inhibited by GW9662. Our results agree with those reported using different NSCLC cell lines [11]. Studies with a great variety of solid and hematological human tumors have demonstrated the antitumor effects of different TZDs [18-20]. It has also been reported that RGZ slowed proliferation but did not induce apoptosis of colon cancer cells [21]. In our model, inhibition of metabolic activity with $1 \mathrm{uM} \mathrm{RGZ}$ was not associated with cell death but most likely with a reversible cell cycle arrest, since after $72 \mathrm{~h}$, cultured cells recovered proliferating capacity. Morosetti et al have found that after drug removal, cells exposed to RGZ 
resumed their proliferation, while cells treated with $\mathrm{PGJ}_{2}$ did not overcome the cytotoxic insult [22]. These differences were associated with an irreversible G2/M arrest induced by $15 \mathrm{~d}-\mathrm{PGJ}_{2}$ and only transiently by RGZ. LMM3 cell viability was not affected by $15 \mathrm{~d}-\mathrm{PGJ}_{2}$. The differences between natural and synthetic ligands can be attributed to distinctive affinities or potency of both ligands in LMM3 cells. RGZ and $15 \mathrm{~d}-\mathrm{PGJ}_{2}$ have been shown to exert antiproliferative effects on human glioblastoma cell lines but only $\mathrm{PGJ}_{2}$ modulated the expression of proteins associated with cell differentiation [22] Differences in the level of PPAR $\gamma$ may also affect the overall sensitivity of a tumor cell to activating ligands. The MCF-7 cell line, which expresses rather low amounts of PPAR $\gamma$ in comparison to other cell lines, was sensitive only at high concentration of PGJs [23] Receptor mutations leading to altered binding affinities or activating effects could also account for differences on sensitivity [24].

Inhibition of LMM3 lung metastatic nodules by RGZ might be associated with the observed decrease in MMP-9 expression. Opposite results have been recently reported demonstrating that, in the HT1080 cell line, pro-MMP-2 was activated by ciglitazone and that the antagonist GW9662, although attenuated PPAR $\gamma$ activation, had no effect on MMP-2 [25]. Cell adhesion and adhesion molecules are critical in the processes of invasion and metastasis. The anti-adhesive properties of RGZ were observed both during the process of LMM 3 cell adhesion and during de-adhesion of already attached cells. It is interesting to note that in early adhesion, BADGE and RGZ showed the same anti-adhesive effect. However, once the cells were already attached, addition of BADGE reversed RGZinduced cell detachment. Combination of RGZ and BADGE showed that BADGE is not a pure antagonist of PPAR $\gamma$ since, in the process of early adhesion; it seemed to act as an agonist ligand. It is noteworthy that loss of LMM3 cell adhesion was not the result of cell death since all detached cells were still alive. It has been reported that $\operatorname{PPAR} \gamma$ inhibitors prevented thyroid and hepatocellular carcinoma cell adhesion by inhibition of FAK phosphorylation and inducing cell death by anoikis $[26,27]$. Furthermore, in a model of colorectal cancer, it was recently observed that BADGE was a potent inhibitor of metastases [28]. It is becoming clear that activation of the same receptor with different ligands may result in different responses. The anti-metastatic activity of RGZ in vivo, without affecting primary tumor growth, might be partially attributed to inhibition of cell adhesion, migration ("wound assay") and invasion (Transwell), the latter being the most sensitive.

The role of PPAR $\gamma$ in tumors has been widely studied. $\operatorname{PPAR} \gamma$ agonists induce apoptosis using fatty acid derivatives, TZDs and tyrosine-based agonists in several cancer cell types [29]. More recently, perturbation of PPAR $\gamma$ expression and activity have been suggested as a therapeutic strategy for several epithelial tumor types [30]. Studies on the expression of PPAR $\gamma$ in LMM3 tumor cells showed that RGZ augmented its expression. PPAR $\gamma$ was detected by immunohistochemistry only in tumors from RGZtreated mice, while surrounding adipocytes and endothelium were stained in treated and control animals. According to these observations, we cannot discard the fact that in vivo, the inflammatory tumor microenvironment (macrophages, lymphocytes, endothelial cells) might regulate PPAR $\gamma$ expression in tumor cells. It has been reported that serum lysophosphatidic acid attenuates both the degree of PPAR $\gamma$ activation and the cellular response to $15 \mathrm{~d}-\mathrm{PGJ}_{2}$ in neuroblastoma cells [31].

The decrease in NO levels in the presence of RGZ was dose-independent. LMM3 cells express COX-1, COX-2, NOS2, NOS3 and arginase II, involved in angiogenesis and tumor cell migration. We provided evidence that $\mathrm{PGE}_{2}$ exerted a positive loop on NOS activity in these tumor cells, augmenting NO levels which closed the loop with a negative feed-back on COX activity [32]. Previoulsy, we have reported that LMM3 cells produce high levels of $\mathrm{NO}$, further increased in the presence of LPS+IFN, which inversely correlated with sensitivity to injury by an exogenous source of NO [33]. In the present experiments, both RGZ and $15 \mathrm{~d}-\mathrm{PGJ}_{2}$ reduced NO production, a survival factor for LMM3 cells (Jasnis MA et al, unpublished data). In other tumor model, we have observed that induction of PPAR $\gamma$ expression by BCG, $15 \mathrm{~d}-\mathrm{PGJ}_{2}$ and RGZ was associated with a decrease in NO production and loss of cell viability [34].

Since inflammation is an important component of tumor progression, we analyzed the effect of an inflammatory stimulus such as LPS on the response of LMM3 cells to RGZ or $15 \mathrm{~d}-\mathrm{PGJ}_{2}$. While NO production was augmented by RGZ, it decreased by $15 \mathrm{~d}-\mathrm{PGJ}_{2}$. Furthermore, LPS reversed cell metabolic inhibition induced by RGZ. It has been reported that LPS suppressed PPAR $\gamma$ expression in human monocytes [35] and in microglial cultures [36]. Agonists of PPAR $\gamma$ are also able to modulate inflammatory responses in several cells by inhibiting the expression of proinflammatory cytokines and of inducible NOS and COX-2 [5,37]. However, other studies have yielded opposite results showing that RGZ increased the inflammatory response in epithelial cells and in macrophages $[38,39]$.

\section{Conclusion}

The current study suggests that RGZ or any other TZDs should be considered as possible future therapeutics in the treatment of metastasis of PPAR $\gamma$-expressing cells. Since we cannot underestimate the influence of the inflammatory milieu of the tumor microenvironment, it 
will be necessary to understand the mechanism of action in a more profound way, and to define under which circumstances these compounds work best in vivo.

\section{Competing interests}

The author(s) declare that they have no competing interests.

\section{Authors' contributions}

GM performed the bulk of experiments in vitro and in vivo as part of PhD Fellowship from ANPCYT and participated in the drafted of the manuscript. XB participated in the in vitro experiments with RR. MAJ conceived the study and participated in its design and coordination. All authors read and approved the manuscript.

\section{Acknowledgements}

This research was supported in part by grant PICT 2003, No. 05-I4088 from FONCYT- ANPCYT (Argentina). We thank Dr Elisa Bal de Kier Joffé for critical reading of this manuscript and Dr Lucas Colombo for technical assistance.

\section{References}

I. Na H-K, Surh Y-J: Peroxisome proliferator-activated receptor gamma (PPARgamma) ligands as bifunctional regulators of cell proliferation. Biochem Pharmacol 2003, 66:|38|-|39|.

2. Clark RB: The role of PPARs in inflammation and immunity. J Leukoc Biol 2002, 7 I:388-400.

3. Kodera Y, Takeyama KI, Murayama A, Suzawa M, Masuhiro Y, Kato S: Ligand type-specific interactions of peroxisome proliferators-activated receptor gamma with transcriptional coactivators. J Biol Chem 2000, 275:3320I-32204.

4. Jiang C, Ting AT, Seed B: PPAR-gamma agonists inhibit production of monocyte inflammatory cytokines. Nature 1998, 39 I:82-86.

5. Ricote M, Li AC, Willson TM, Kelly CJ, Glass CK: The peroxisome proliferator-activated receptor-gamma is a negative regulator of macrophage activation. Nature 1998, 39 I:79-82.

6. Koeffler HP: Peroxisome proliferator-activated receptor gamma and cancers. Clin Cancer Res 2003, 9:1-9.

7. Weng JR, Chen CY, Pinzone JJ, Ringel MD, Chen SC: Beyond peroxisome proliferator-activated receptor gamma signaling: the multi-facets of the antitumor effect of thiazolidinediones. Endocr Relat Cancer 2006, 13:40 I-4I3.

8. Niho N, Takahashi M, Kitamura T, Shoji Y, Itoh M, Noda T, Sugimura $\mathrm{T}$, Wakabayahsi K: Concomitant suppression of hyperlipidemia and intestinal polyp formation in Apc-deficient mice by peroxisome-proliferator activated receptor ligands. Cancer Res 2003, 63:6090-6095

9. Liu H, Zang C, Fenner MH, Possinger K, Elstner E: PPARgamma ligands and ATRA inhibit the invasion of human breast cancer cells in vitro. Breast Cancer Res Treat 2003, 79:63-74.

10. Wright HM, Clish CB, Mikami T, Hauser S, Yanagi K, Hiramatsu R, Serhan CN, Spiegelman BM: A synthetic antagonist for the peroxisome proliferator-activated receptor gamma inhibits adipocyte differentiation. | Biol Chem 2000, 275: I873-I877.

II. Han SW, Roman J: Rosiglitazone suppress human lung carcinoma cell growth through PPAR $\gamma$-dependent and PPAR $\gamma$,independent signal pathways. Mol Cancer Ther 2006, 5:430-437.

12. Urtreger AJ, Ladeda VE, Puricelli LI, Rivelli A, Vidal MC, Lustig ES, Bal de Kier Joffe E: Modulation of fibronectin expression and proteolytic activity associated with the invasive and metastatic phenotype in two murine mammary tumor cell lines. Int J Oncol 1997, I I:489-496.

13. Granger DL, Hidds JB, Perfects JR, Durack DT: Metabolic fate of Larginine inhalation to microbiostatic capability of murine macrophages. J Clin Invest 1990, 85:264-267.
14. Lea MA, Sura M, Desbordes C: Inhibition of cell proliferation by potential peroxisome proliferator-activated receptor (PPAR) gamma agonists and antagonists. Anticancer Res 2004, 24:2765-277I.

15. Nakamuta M, Enjoji M, Uchimura K, Ohta S, Sugimoto R, Kotoh K, Kato M, Irie T, Muta T, Nawata $\mathrm{H}$ : Bisphenol A diglycidyl ether (BADGE) suppresses tumor necrosis factor-alpha production as a PPARgamma agonist in the murine macrophagelike cell line RAW 264.7. Cell Biol Int 2002, 26:235-24I.

16. Bishop-Bailey D, Hla T, Warner TD: Bisphenol A diglycidyl ether (BADGE) is a PPARgamma agonist in an ECV304 cell line. $\mathrm{Br}$ J Pharmacol 2000, 131:651-654

17. Fehlberg S, Trautwein S, Goke A, Goke R: Bisphenol A diglycidyl ether induces apoptosis in tumour cells independently of peroxisome proliferator-activated receptor-gamma, in caspase-dependent and -independent manners. Biochem J 2002, 362:573-578.

18. Liu DC, Zang CB, Liu HY, Possinger K, Fan SG, Elstner E: A novel PPAR alpha/gamma dual agonist inhibits cell growth and induces apoptosis in human glioblastoma T98G cells. Acta Pharmacol Sin 2004, 25:1312-1319.

19. Rumi M, Sato H, Ishihara S, Kawashima K, Hamamoto S, Kazumori H, Okuyama T, Fukuda R, Nagasue N, Kinoshita Y: Peroxisome proliferator-activated receptor gamma ligand-induced growth inhibition of human hepatocellular carcinoma. $\mathrm{Br} j$ Cancer 200I, 84: I640-1647.

20. Takenokuchi M, Saigo K, Nakamachi Y, Kawano S, Hashimoto M, Fujiota T, Koizumi T, Tatsumi E, Kumagai S: Troglitazone inhibits cell growth and induces apoptosis of B-cell acute lymphoblastic leukemia cells with $t(14 ; 18)$. Acta Haematol 2006, I I6:30-40.

21. Gupta RA, Brockman JA, Sarraf P, Willson TM, DuBois RN: Target genes of Peroxisome proliferators-activated receptor gamma in colorectal cancer cells. J Biol Chem 200I, 276:2968I-29687.

22. Morosetti R, Servidei T, Mirabella M, Rutella S, Mangiola A, Maira G, Mastrangelo R, Koeffler HP: The PPARgamma ligands PGJ2 and rosiglitazone show a differential ability to inhibit proliferation and to induce apoptosis and differentiation of human glioblastoma cell lines. Int J Oncol 2004, 25:493-502.

23. Yee LD, Saboudin CL, Liu L, Li HM, Smith PJ, Seewaldt V, Kniss DA Peroxisome proliferator-activated receptor gamma activation in human breast cancer. Int J Oncol 1999, 15:967-73.

24. Sarraf P, Mueller E, Smith WM, Wright HM, Kum JB, Aaltonen LA, de la Chapelle A, Spiegelman BM, Eng C: Loss-of-function mutations in PPAR gamma associated with human colon cancer. Mol Cell 1999, 3:799-804.

25. Kin KH, Cho YS, Park JM, lon SO, Kim KW, Chung AS: Pro-MMP-2 activation by the PPAR $\gamma$ agonist ciglitazone, induces cell invasion through the generation of ROS and the activation of ERK. FEBS Letters 2007, 58 I:3303-3310.

26. Chen Y, Wang SM, Wu JC, Huang SH: Effects of PPARgamma agonists on cell survival and focal adhesion in a Chinese thyroid carcinoma cell line. I Cell Biochem 2006, 98: I02I-1035.

27. Schaefer KL, Wada K, Takahashi H, Matsuhashi N, Ohnishi S, Wolfe MM, turner JR, Nakajima A, Borkan SC, Saubermann LJ: Peroxisome proliferator-activated receptor gamma inhibition prevents adhesion to the extracellular matrix and induces anoikis in hepatocellular carcinoma cells. Cancer Res 2005, 65:225I-2259.

28. Schaeffer KL, Takahashi H, Morales VM, Harris G, Barton S, Osawa E, Nakajima A, Saubermann L: PPAR $\gamma$ inhibitors reduce tubulin protein levels by a PPAR $\gamma$, PPAR $\delta$ and proteasome-independent mechanism, resulting in cell cycle arrest, apoptosis and reduced metastasis of colorectal carcinoma cells. Int J Cancer 2006, 120:702-7I3

29. Wang T, Xu J, Yu X, Yang R, Hanz ZC: Peroxisome proliferatoractivated receptor gamma in malignant diseases. Crit Rev Oncol Hematol 2006, 58: I- 14.

30. Wang $X$, Kilgore MW: Signal cross-talk between estrogen receptor alpha and beta and the peroxisome proliferatoractivated receptor gamma in MDA-MB-23I and MCF-7 breast cancer cells. Mol Cell Endocrinol 2002, 194:123-133.

31. Rodway HA, Hunt AN, Kohler JA, Postle AD, Lillycrop KA: Lysophosphatidic acid attenuates the cytotoxic effects and degree of peroxisome proliferator-activated receptor gamma activation induced by |5-deoxyDelta | 2, | 4-prostaglandin J2 in neuroblastoma cells. Biochem J 2004, 382:83-91. 
32. Davel L, Dagostino A, Español A, Jasnis MA, Lauria de Cidre L, de Lustig ES, Sales ME: Nitric oxide synthase-cyclooxygenase interactions are involved in tumor cell angiogenesis and migration. J Biol Regul Homeost Agents 2002, 16:181-189.

33. Eijan AM, Davel LE, Rueda HA, Rosemberg G, De Lustig ES, Jasnis MA: Differential nitric oxide release and sensitivity to injury in different murine mammary tumor cell lines. Int J Mol Med 1998, 2:625-630.

34. Lodillinsky C, Umerez MS, Jasnis MA, Casabe A, Sandes E, Eijan AM: Bacillus Calmette-Guerin induces the expression of peroxisome proliferator-activated receptor gamma in bladder cancer cells. Int J Mol Med 2006, 17:269-73.

35. Hinz B, Brune K, Pahl A: I 5-Deoxy-Delta (12, 14)-prostaglandin $\mathrm{J2}$ inhibits the expression of proinflammatory genes in human blood monocytes via a PPAR-gamma-independent mechanism. Biochem Biophys Res Commun 2003, 302:4I5-420.

36. Bernardo A, Levi G, Minghetti L: Role of the peroxisome proliferator-activated receptor-gamma (PPAR-gamma) and its natural ligand 15-deoxy-delta I2, I4-protaglandin J2 in the regulation of microglial functions. Eur J Neurosci 2000, I 2:2215-2223.

37. Jiang C, Ting AT, Seed B: PPAR-gamma agonists inhibit production of monocyte inflammatory cytokines. Nature 1998, 391:82-86.

38. Desmet C, Warzée B, Gosset P, Mélotte D, Rongvaux A, Gillet L, Fievez L, Seumois G, Vanderplasschen A, Staels B, Lekeux P, Bureau F: Pro-inflammatory properties of thizolidinediones. Biochem Pharmaco 2005, 69:255-265.

39. Cheron A, Peltier J, Perez J, Bellocq A, Fouqueray B, Baud L: I5 deoxy-Delta I2, 14-prostaglandin J2 inhibits glucocorticoid binding and signaling in macrophages through a peroxisome proliferator-activated receptor gamma-independent process. J Immunol 2004, I72:7677-7683.

\section{Pre-publication history}

The pre-publication history for this paper can be accessed here:

http://www.biomedcentral.com/1471-2407/8/47/prepub
Publish with Biomed Central and every scientist can read your work free of charge

"BioMed Central will be the most significant development for disseminating the results of biomedical research in our lifetime. "

Sir Paul Nurse, Cancer Research UK

Your research papers will be:

- available free of charge to the entire biomedical community

- peer reviewed and published immediately upon acceptance

- cited in PubMed and archived on PubMed Central

- yours - you keep the copyright 